\title{
NOTE
}

\section{Virus-associated epidermal hyperplasia in golden ide Leuciscus idus melanotus}

\author{
Dieter Steinhagen, Peter Kruse, Manfred Neukirch
}

Fish Diseases Research Unit, School of Veterinary Medicine, Bünteweg 17, W-3000 Hannover 71, Germany

\begin{abstract}
Epidermal hyperplasia on the skin and fins of 8 to 9 mo old golden ide was associated with the presence of herpesvirus-like particles. Virions were found in the nucleus and as enveloped particles within intracytoplasmic vacuoles. Accumulations of infected cells were enveloped by fibroblastic cells and granulocytes were present in these areas. Attempts to isolate this virus using the fathead minnow (FHM) and epithelioma papillosum cyprini (EPC) cell lines were unsuccessful.
\end{abstract}

Golden ide Leuciscus idus melanotus are often kept as ornamental fish in garden ponds and furthermore, are used as test fish for toxicologic monitoring. For these reasons golden ide have been included in survey programs on fish disease control.

Numerous reports of epidermal hyperplasia of fish with putative or known viral etiologies have been published. In many cases, herpesviruses have been shown to be associated with epidermal proliferations but adenoviruses, papovaviruses and retrovirus-like particles have also been suspected causes of the hyperplasia (for references see Anders 1989). Herpesviruses of proven oncogenicity have been isolated from masu salmon Oncorhynchus masou: including Oncorhynchus masu virus (OMV) by Kimura et al. (1981) and the Yamame tumour virus (YTV) by Sano et al. (1983). A third herpesvirus from Asagi carp Cyprinus carpio, termed Herpesvirus cyprini, has also been isolated and shown to induce epidermal hyperplasia under experimental conditions (Sano et al. 1985a, b). Previous attempts to isolate the causative agent associated with epithelioma-like lesions from golden ide failed (McAllister et al. 1985). In this communication ultrastructural observations of epidermal hyperplasia developed in golden ide and of virus particles isolated from affected fish are presented.
Materials and methods. Fish: Juvenile golden ide, ca 10 to $12 \mathrm{~cm}$ body length, with epidermal hyperplasia were obtained from ponds of a commercial fish farm near Hannover (Germany) in February and March 1989 and 1990. This hatchery has had a history of epithelioma-like growth in their carp.

Light and electron microscopy: Both histological and electron microscopical observations were made from epidermal hyperplasia bearing tissue fixed with $2.5 \%$ glutaraldehyde in $0.1 \mathrm{M}$ cacodylate buffer ( $\mathrm{pH} 7.4$ ). Tissues were postfixed in $1 \% \mathrm{O}_{5} \mathrm{O}_{4}$ in the same buffer, dehydrated in a series of ascending grades of ethanol and embedded in Spurr's resin. Cell cultures inoculated with extracts from affected tissues were scraped from the culture vessels, fixed in the same solution and then processed as described above. Thick sections $(0.5 \mu \mathrm{m})$ were stained with toluidine blue-fuchsin and observed and photographed in a Zeiss Photomicroscope III. Thin sections ( 60 to $150 \mathrm{~nm}$ ) were stained with uranyl acetate and lead citrate and examined with a Zeiss EM $10 \mathrm{~A}$ electron microscope. Particle dimensions $(n=20)$ were measured on photographic prints.

Virological examinations: Material from epidermal hyperplasia and pooled samples of kidney and spleen material from affected fish were collected separately and processed by standard virological procedures (Neukirch 1984). Extracts from infected tissues were used to inoculate monolayers of fathead minnow (FHM) and epithelioma papillosum cyprini (EPC) cell cultures. The cell cultures were incubated at $20^{\circ} \mathrm{C}$ and observed daily for the development of cytopathogenic effects (CPE). Supernatants from inoculated cell cultures were used to inoculate additional monolayers when CPE was not observed after $10 \mathrm{~d}$. Cells were observed for an additional $10 \mathrm{~d}$ for evidence of CPE. 

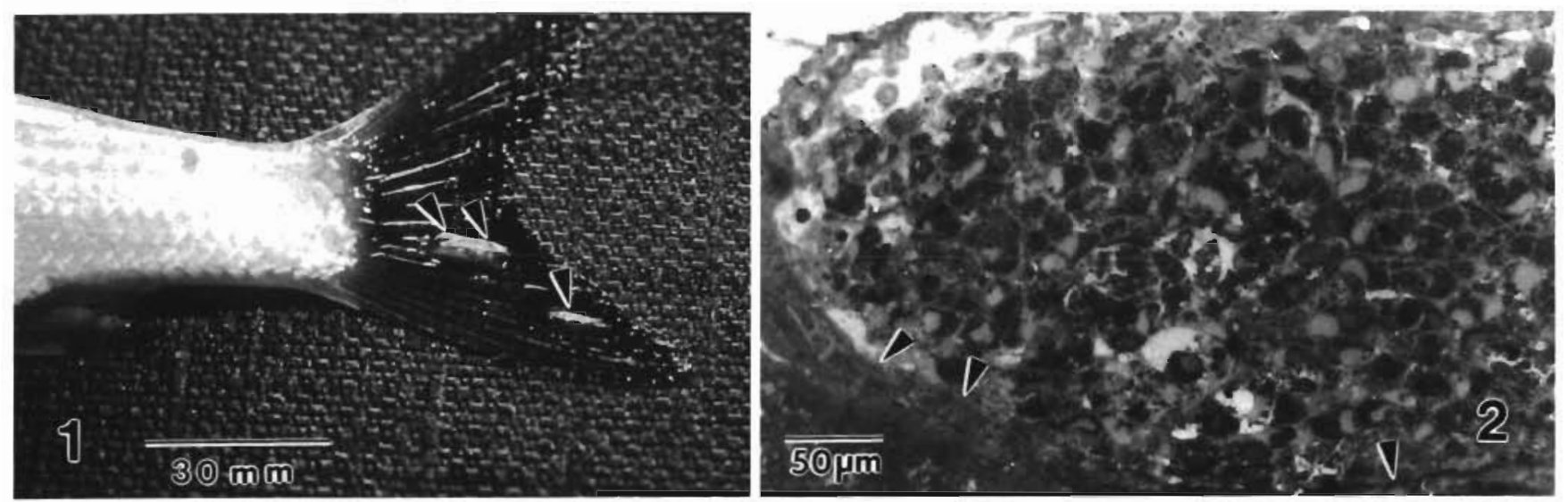

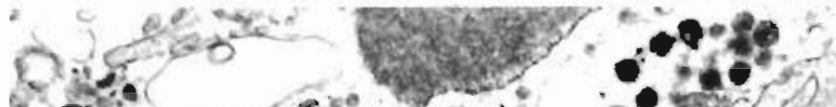

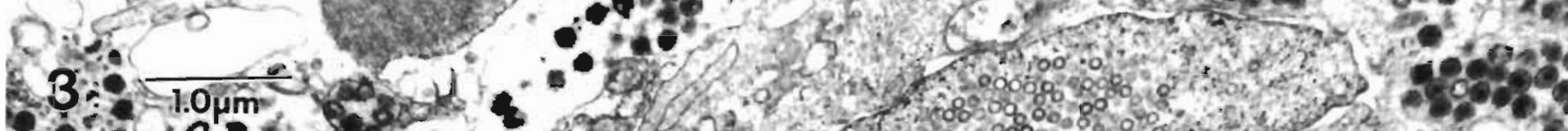

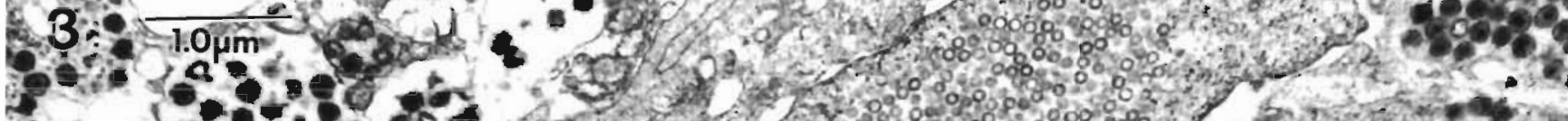

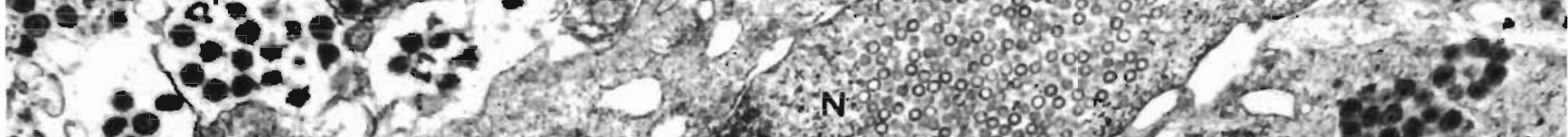

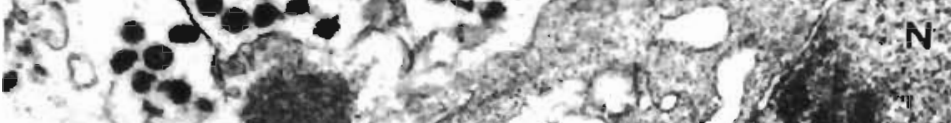
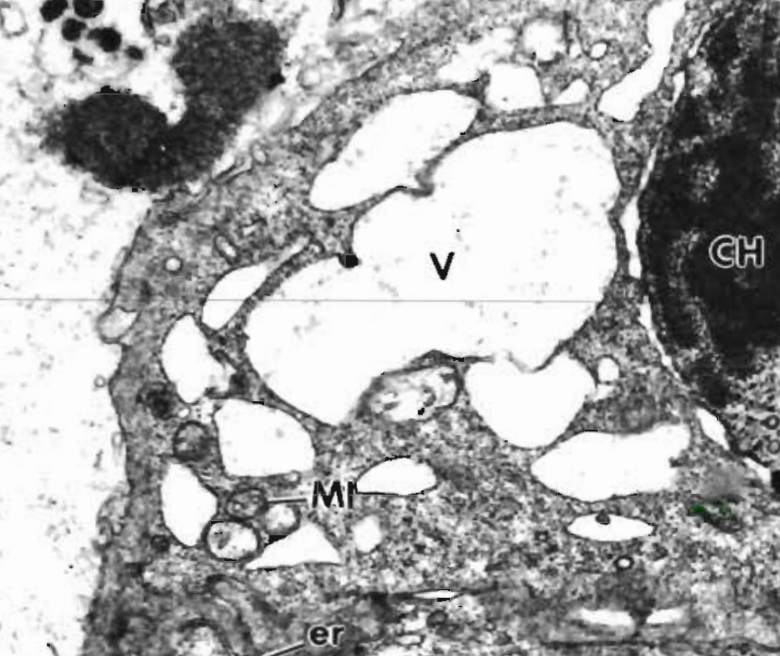
H.t.

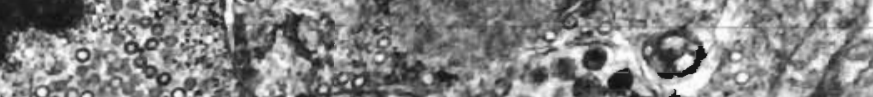

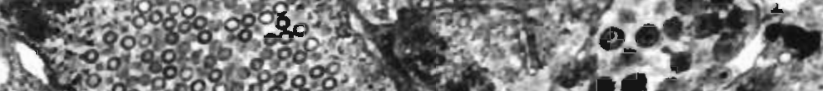

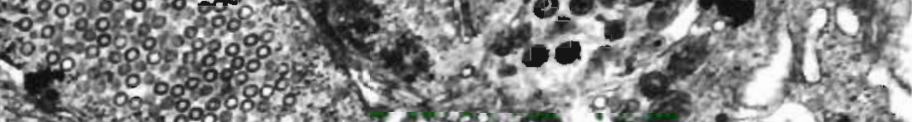

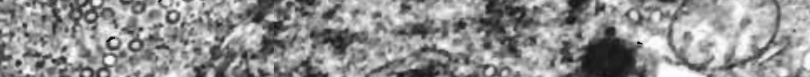

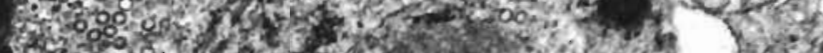

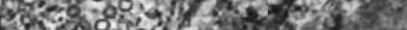

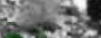

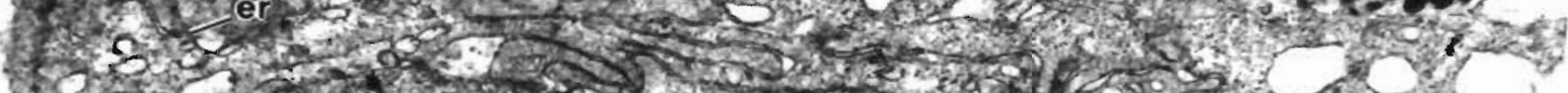

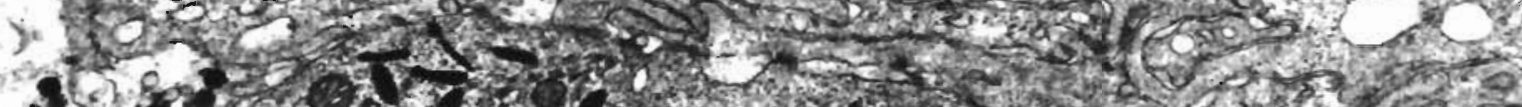

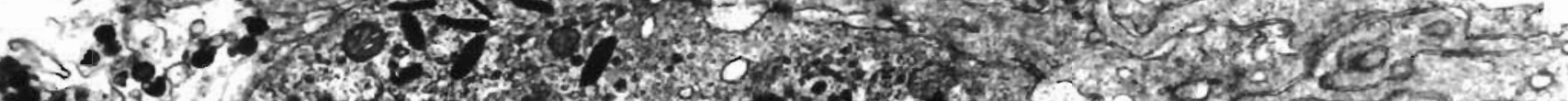

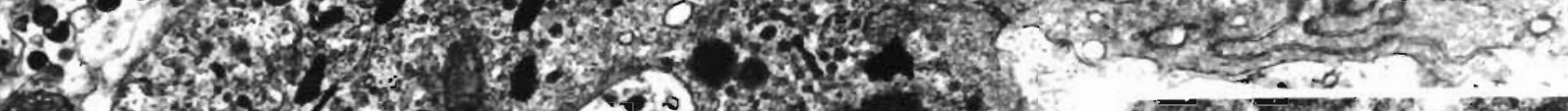

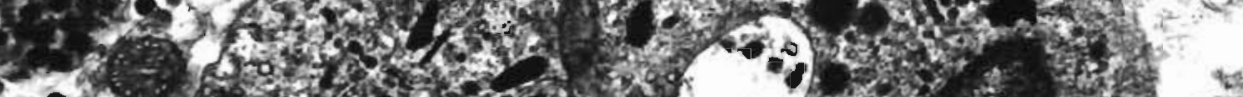

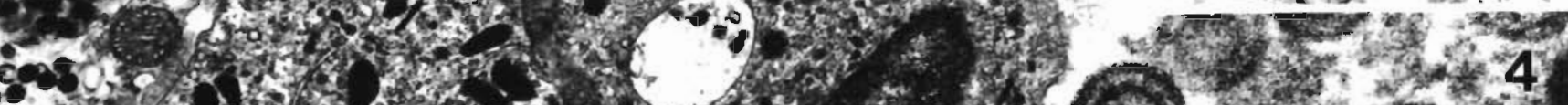

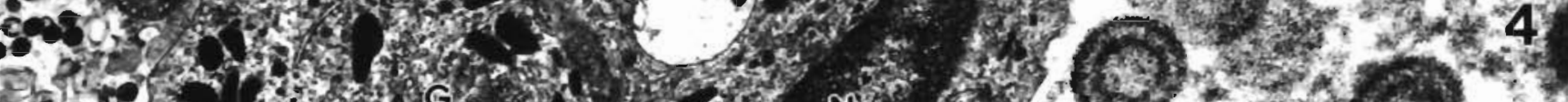

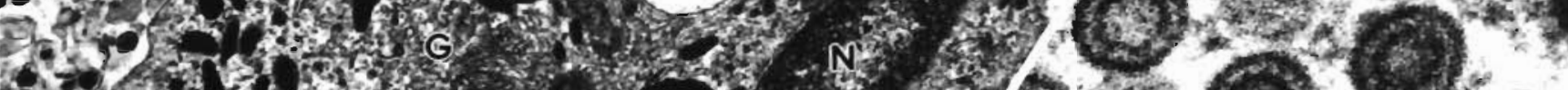
1.

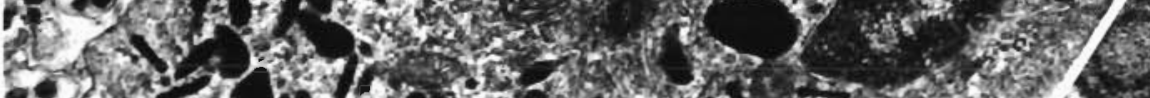

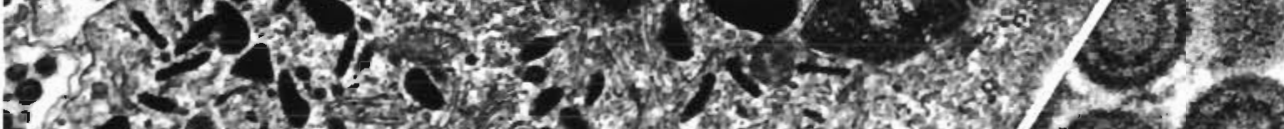

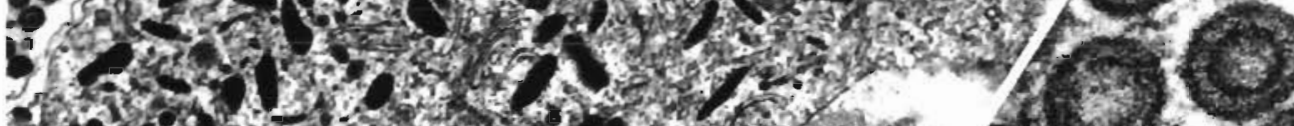

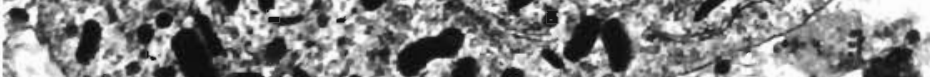

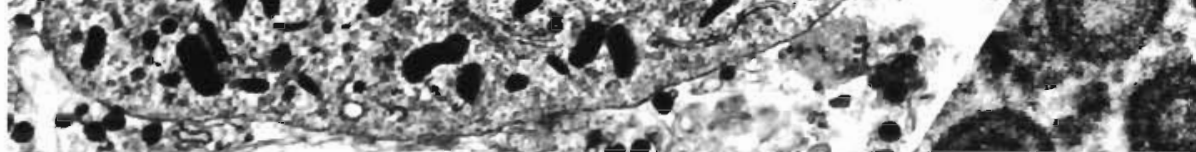


Results and discussion. Spherical, pinhead-sized nodules of whitish opaque appearance were observed on the fins (Fig. 1) and occasionally on the head and trunk of golden ide from the hatchery population during February and early March of 1989 and 1990 (water temperature 6 to $8^{\circ} \mathrm{C}$ ). There were no other signs of disease and with rising water temperatures the nodules disappeared. There were no mortalities.

The nodules were located superficially in the epidermal tissue and did not affect the supporting rays of fins. By light microscopy, intensely stained granules arranged in discrete clusters were observed in the cytoplasm of cells of the epidermal hyperplasia. The area of these cells was encircled by a prominent cystic envelope and hyperplasia of the epithelium was obvious (Fig. 2).

The cells within the nodules contained numerous viral particles at different stages of development. The cells often had a hypertrophic nucleus containing large numbers of unenveloped viruses. Chromatin was found in small marginal areas of the nucleus or was absent (Fig. 3). The intranuclear virions consisted of an outer nucleocapsid of 90 to $110 \mathrm{~nm}$ in diameter surrounding an inner core of 60 to $80 \mathrm{~nm}$ (Fig. 4). In some cases, the inner core contained a condensed electron-dense material. The perinuclear cisternae of infected nuclei appeared to be dilated, and next to the nucleus the cytoplasm of the cell contained high numbers of irregularly arranged fibrous structures (Fig. 5). The cytoplasm of infected cells was highly vacuolated, harbouring dilated mitochondria and cisternae of the endoplasmic reticulum (Figs. $3 \& 6$ ). In many cases, the cytoplasm of these cells was completely filled with clusters of rounded inclusions consisting of an electrondense core ( 60 to $80 \mathrm{~nm}$ ) surrounded by an electronlucent space. These particles appeared to be located singly in a membrane-bound vesicle measuring 160 to $180 \mathrm{~nm}$ (Figs. $6 \& 7$ ). These intracytoplasmic virus particles aggregated in membrane-bound clusters (Fig. 6).

The cystic envelope of the area with infected cells consisted of 2 densely packed layers of fibrous structures embedded in an amorphous substance. These layers enclosed 1 to 2 layers of fibroblastic cells and some granulocytes (Fig. 8). A few granulocytes were also present among the infected cells (Fig. 3).

No CPE was observed in FHM and EPC cell cultures inoculated with homogenized tumour material or with blind passage materials, Evidence of CPE, however, was found in both EPC and FHM cell cultures inoculated with homogenized internal organs from a single golden ide. In cells from these cultures, virus-like intracytoplasmic particles could be observed in the electron microscope, but the ultrastructural features of these particles (diameter ca $63 \mathrm{~nm}$, central condensed electron-dense core ca $21 \mathrm{~nm}$ ) were different from those described above (Fig. 9). Identification of this virus by chemical, biochemical and physical characteristics is in progress.

The viral particles associated with epidermal hyperplasia in golden ide are morphologically and developmentally consistent with herpesviruses. Nucleocapsids were found in the nucleus and mature virions concentrated in membrane-bound vesicles in the cytoplasm of infected cells. Infections with herpesviruses have been reported from many feral and ornamental fishes (for review see Anders 1989, Hedrick \& Sano 1989 and Wolf 1988). These infections may be associated with signs of disease. Most of the herpesviruses of fishes have been associated with skin infections and have been observed only by election microscopy. However, at least 2 herpesviruses were isolated in cell culture (Hedrick \& Sano 1989), and their oncogenic potential demonstrated (Kimura et al. 1983, Sano et al. 1983). A cyprinid herpesvirus has similarly been isolated and demonstrated experimentally to induce hyperplasia and also mortality in young fish (Sano et al. 1985a, b).

Among golden ide originally imported from Germany, McAllister et al. (1985) described an infection with a herpesvirus which was associated with white plaque-like lesions of skin and fins. The viral particles they described (dimensions: enveloped particles ca $115 \mathrm{~nm}$, capsid ca $60 \mathrm{~nm}$, core ca $53 \mathrm{~nm}$ ) differ somewhat from those observed in this study (160 to $180 \mathrm{~nm}$, 90 to $110 \mathrm{~nm}, 60$ to $80 \mathrm{~nm}$ respectively), but morphological and pathological characteristics of the particles and skin lesions are similar. This most likely indicates that the virus described by McAllister et al. (1985) and the one described here are identical pathogens. The differences in size may represent differences in specimen preparation. Viral particles from golden ide were also very similar to those associated with epithelioma papillosum of common carp Cyprinus carpio (Schubert 1964, 1966, Sano et al. 1985a, b).

Figs. 1 to 4, Leuciscus idus. Epidermal hyperplasia. Fig. 1. Whitish opaque nodules on caudal fin. $\times 1.5$. Fig. 2. Nodules have cystic structure and contain virus-infected cells with granular inclusions and are enclosed by hyperplastic epidermal cells (arrowheads). Light micrograph, $\times 230$. Fig. 3. Infected tissue with cells bearing viral particles in nucleus ( $N$ ) and cytoplasm. The cytoplasm is highly vacuolated. Among infected celis granulocytes (G) are present. $\mathrm{CH}$ : chromatin; er: cisternae of the endoplasmic reticulum; MI: mitochondrion; V: vacuole. $\times 14700$. Fig. 4. Intranuclear viral particles. $\times 134000$ 

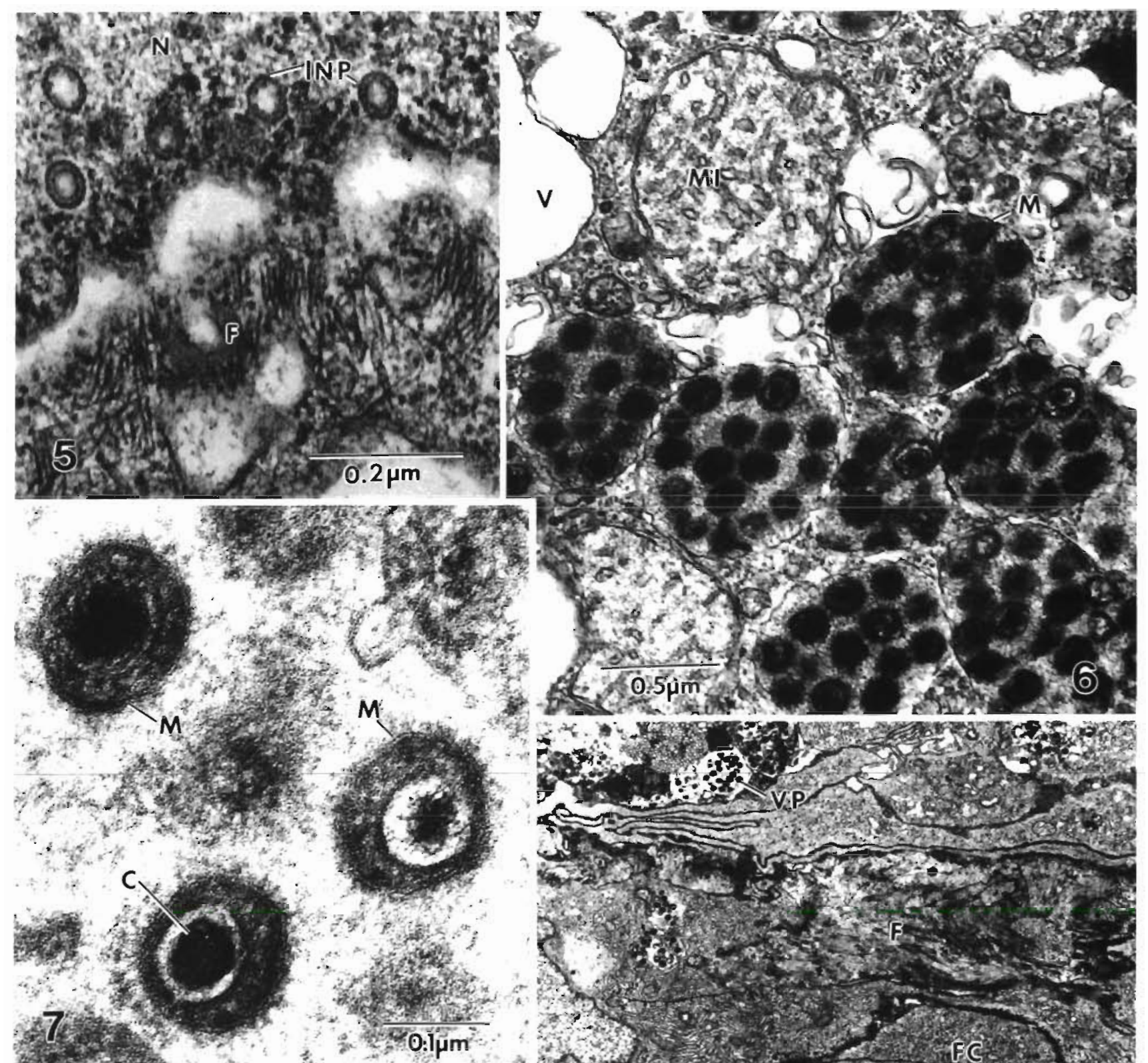

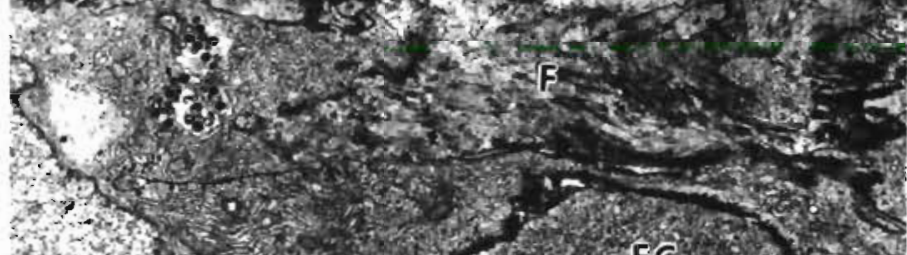

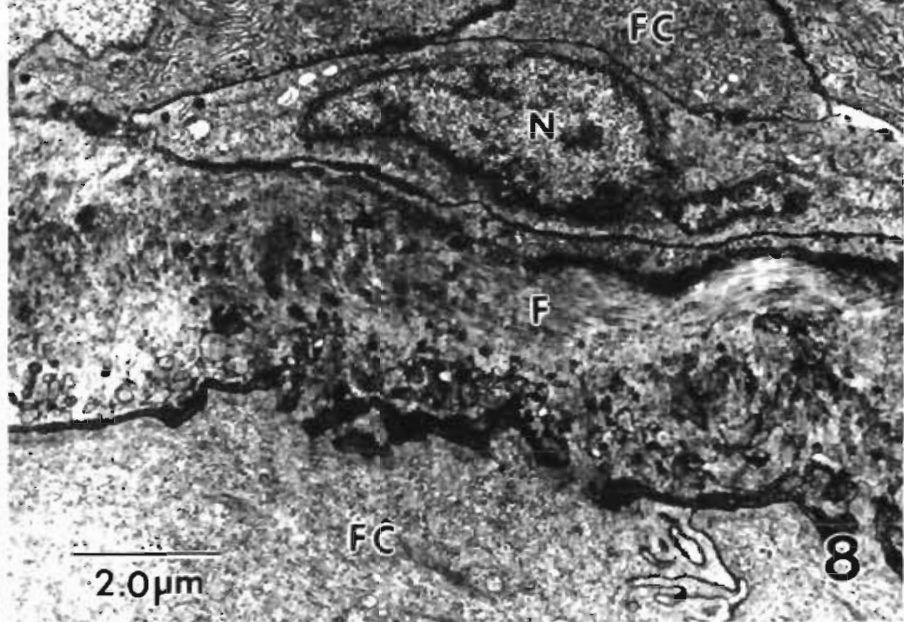


Figs. 5 to 9. Leuciscus idus. Epidermal hyperplasia. Fig. 5. Infected cell with intranuclear virions (INP) and numerous fibrils (F) in the cytoplasm surrounding the perinuclear cisternae, N: nucleus. $\times 68000$. Fig. 6 . Cytoplasm of infected cells shows vacuolization, dilated mitochondria (MI) and membrane bound aggregates of enveloped viral particles. M: membrane; V: vacuole. $\times 36700$. Fig. 7. Intracytoplasmic viral particles enveloped by a unit membrane (M). C: core. $\times 157400$. Fig. 8 . The cystic envelope is composed of 2 layers of cells with densely packed fibrils $(F)$, between which fibroblastic cells $(\overrightarrow{F C})$ are enclosed. N: nucleus; VP: viral particles. $\times 7600$. Fig. 9 . Viral particles from tissue culture. $\times 166000$

Attempts to isolate the herpesvirus from golden ide in our study and by McAllister et al. (1985) and from epithelioma papillosum of koi carp (Hedrick \& Sano 1989) were unsuccessful.

Epidermal hyperplasia as observed in our study and others was seasonal with fish being affected mainly in early spring (McAllister et al. 1985) and early summer (Hedrick \& Sano 1989). Temperature-dependent replication of herpesviruses of fish has been observed. Herpesvirus vitrieum from hyperplastic epidermal tissue of walleye Stizostedion vitreum vitreum replicated at 4 and $15^{\circ} \mathrm{C}$ but not at $20^{\circ} \mathrm{C}$, a temperature most suitable for walleye ovary (WO) cell growth (Kelly et al. 1983).

Epidermal hyperplasia is a common phenomenon in fish and is caused by a wide variety of agents (Ferguson 1989). Pathological changes of cells and tissue associated with virus-induced hyperplasia in golden ide as described in this study are similar to those observed in so called 'carp pox' (Schubert 1964). We observed the formation of a fibroblastic envelope surrounding areas of infected cells and granulocytes among infected cells within the envelope, all suggesting strong host defence reaction. This host response in combination with the effects of temperature on virus replication may explain the seasonal nature of the observed epidermal hyperplasia in golden ide.

Acknowledgements. Electron microscopic investigations were performed using the equipment of the Electron Microscopy Working Group, Botany Department, School of Veterinary Medicine, Hannover. We are grateful to the reviewers who helped to improve earlier versions of this manuscript.

Responsible Subject Editor: F. M. Hetrick, College Park, Maryland, USA

\section{LITERATURE CITED}

Anders, K. (1989). A herpes virus associated with an epizootic epidermal papillomatosis in European smelt (Osmerus everlans). In: Ahne, W., Kurstak, E. (eds.) Viruses of lower vertebrates. Springer, Berlin, p. 184-197

Ferguson, H. W. (1989). Systemic pathology of fishes. Iowa State University Press, Ames

Hedrick, R. P., Sano, T (1989). Herpesviruses of fish. In: Ahne, W. Kurstak, E. (eds.) Viruses of lower vertebrates. Springer, Berlin, p. 161-170

Kelly, R. K., Nielsen, O., Mitchell, S. C., Yamamoto, T (1983). Characterization of Herpesvirus vitreum from hyperplastic epidermal tissue of walleye, Stizostedion vitreum vitreum (Mitchill). J. Fish Dis. 6: 249-260

Kimura, T., Yoshimizu, M., Tanaka, M. (1981). Studies on a new virus (OMV) from Oncorhynchus masou. II. Oncogenic nature. Fish Pathol. 15: 149-153

McAllister, P. E., Lidgerding, B. L., Herman, R. L., Hankins, J. (1985). Viral diseases of fish: first report of carp pox in golden ide (Leuciscus idus) in North America. J. Wildl. Dis. $21 \quad 119-204$

Neukirch, M. (1984). An experimental study on the entry and multiplication of viral haemorrhagic septicaemia in rainbow trout, Salmo gairdneri Richardson. J. Fish Dis. 7: $231-234$

Sano, T., Fukuda, H., Okamoto, N., Kaneko, F. (1983). Yamame tumour virus: lethality and oncogenicity. Bull. Jap. Soc. Sci. Fish 49: 1159-1163

Sano, T., Fukuda, H., Furukawa, M. (1985a). Herpesvirus syringa: biological and oncogenic properties. Fish Pathol. 20: $381-388$

Sano, T., Fukuda, H., Furukawa, M., Hosoya, H., Moriya, Y. (1985b). A herpesvirus isolated from carp papilloma in Japan. In: Ellis, A.E. (ed.) Fish and shellfish pathology. Academic Press, London, p. 307-311

Schubert, G. (1964). Elektronenmikroskopische Untersuchungen zur Pockenkrankheit des Karpfens. Z. Naturforsch. $19 b: 675-682$

Schubert, G. (1966). The infective agent in carp pox. Bull. Off. Int. Epizoot. 65: 1011-1022

Wolf, K. (1988). Fish viruses and viral diseases. Cornell University Press, Ithaca

Manuscript first received: March 4, 1991

Revised version accepted: June 17, 1992 